6. Finkelstein J, Duhau M, Speranza A. Evolución de la mortalidad infantil en Argentina en el marco de los Objetivos de Desarrollo del Milenio. Arch Argent Pediatr 2016; 114(3):216-22.

7. Lawn J, Blencowe $\mathrm{H}$, Pattinson R, et al. Stillbirths: Where? When? Why? How to make the data count? Lancet 2011; 377(9775):1448-63.

8. Grandi C, Nascente L, Cardoso V. Impacto de la mortalidad fetal sobrela prematurez en Argentina: estudio poblacional. Rev Fac Cien Med 2017; 74(4).

9. Barker DJ. The developmental origins of chronic adult disease. Acta Paediatr Suppl 2004; 93(446):26-33.

10. Blencowe H, Cousens S, Oestergaard MZ, et al. National, regional, and worldwide estimates of preterm birth rates in the year 2010 with time trends since 1990 for selected countries: a systematic analysis and implications. Lancet 2012;379(9832):2162-72

\title{
Predatory journals
}

Very frequently, those who are reading these lines have received persistent messages inviting them to send an article for publication in a scientific journal. Sometimes, these messages acclaim the characteristics of an absolutely unknown article; it is also not unusual that they appeal to your vanity by highlighting your alleged expertise in a certain topic.

Messages usually go like this: "Dear Professor ....................., we have read your article titled 'Prevalence of predatory journals worldwide'. We are impressed by the quality of your work and we are contacting you to ask you to submit your next study on this topic." Using the same modality, they usually invite you to become part of the editorial committees of journals with a name that is "similar" to those of renowned scientific publications.

What is hidden behind all this? This type of messages is mostly part of the so-called "predatory journals" world, whose main objective is to make money, in an unethically but not illegal manner. These journals show little or no care at all regarding the quality of the articles they publish, fail to follow best practice standards for academic publications, and impose a fee on the author, who finances the publication of his/her work. ${ }^{1}$

The term "predatory journals" was coined in 2010 by Jeffrey Beall, a librarian at the University of Colorado, who created a blog where he published a list of journals and publishers carrying out such practice. The blog generated a big controversy, including editorial comments and legal claims in both directions, which ended up in him taking down his blog in $2017 .^{2}$

The usual practice of predatory journals includes some of the following characteristics: ${ }^{3}$

- They promise publication in short time.

- They claim a false impact factor.
- Their assessment fee is unclear.

- Their office address is not entirely transparent.

- Their name is similar to that of renowned journals.

- Electronic spamming.

\section{When did it all start?}

Many people have pointed out that the problem started with the open access initiative. ${ }^{4}$ This emerged from the combination of several factors: on the one side, the pressure to "publish or die" in the academic setting led to the existence of more and more manuscripts available for a limited number of journals willing to publish them. On the other side, the advent of the Internet and the subsequent changes in the publishing business, the globalization of knowledge, and the pressure for free access to such knowledge have led to questioning the limitation of scientific information imposed by large publisher groups. ${ }^{5}$ Finally, the great number of journals that we need to access to be updated makes it financially unsustainable to subscribe to all of them, either at an individual or institutional level.

The open access initiative seeks to obtain free access to all scientific information available online. Given that scientific journals bear an unavoidable cost that would be left uncovered without readers' subscription, it was suggested that authors should take over the publication step by paying what is known as an "article processing fee." Such processing includes the controls a good journal should conduct to avoid publishing articles without scientific merit or that are clearly fraudulent. Unfortunately, this altruistic initiative brought about unscrupulous groups that only sought a financial return: predatory journals. They disseminate manuscripts in exchange for an article processing fee but their thirst for profit 
and the lack of effective publishing controls leads them to publish research articles with a very low quality or even fraudulent.

\section{What is the result of this practice? ${ }^{1}$}

Authors who, even after being warned, decide to approach the world of predatory journals, should be aware of the risks. Their articles will not be submitted to peer-review, a practice that is known to improve the scientific quality of a manuscript. Besides, their articles may disappear from the web after some time, considering how unstable these companies may be. Articles may be difficult to find because they are not indexed in any reliable database. And finally, it may be humiliating to find your article associated with the suspicion generated by a predatory journal, whose lack of earnestness has already been exposed. ${ }^{6,7}$

The endorsement of a scientific journal lies in its prestige, built on the foundation of the strict control of the published material, scientific rigor, and intellectual honesty. Such prestige endorses each published investigation and allows both authors and readers to trust the sound academic background of its contents

Verónica Aguerre, M.D. Hospital de Pediatría SAMIC "Prof. Dr. Juan P. Garrahan"

Fernando Ferrero, M.D. Hospital General de Niños "Pedro de Elizalde" http:/ / dx.doi.org/10.5546/ aap.2018. eng.240

To cite: Aguerre V, Ferrero F. Predatory journals. Arch Argent Pediatr 2018;116(4):240-241.

\section{REFERENCES}

1. O'Donell M. Understanding Predatory Publishers. Library guides. Iowa State University. [Accessed on: March 20th, 2018]. Available at: http://instr.iastate.libguides.com/ predatory.

2. Beall J. What I learned from predatory publishers. Biochem Med (Zagreb) 2017; 27(2):273-8.

3. Beall J. Best practices for scholarly authors in the age of predatory journals. Ann R Coll Surg Engl 2016; 98(2):77-9.

4. Björk BC, Welling P, Laakso M, et al. Open Access to the Scientific Journal Literature: Situation 2009. PLoS One 2010; 5(6):e11273.

5. Monbiot G. Academic publishers make Murdoch look like a socialist. The Guardian. London: 2012 August 29. [Accessed on: March 20th, 2018]. Available at: https:// www.theguardian.com/commentisfree/2011/aug/29/ academic-publishers-murdoch-socialist.

6. Sorokowski P, Kulczycki E, Sorokowska A, et al. Predatory journals recruit fake editor. Nature 2017; 543(7646):481-3.

7. Bohannon J. Who's afraid of peer review? Science 2013; 342(6154):60-5. 